\title{
АЛЬТЕРНАТИВНИЙ МЕТОД ВИЗНАЧЕННЯ ПОСУХОСТІЙКОСТІ РІПАКА ОЗИМОГО НА РАННІХ ЕТАПАХЙОГО РОЗВИТКУ
}

Н. А. Глухова

Інститут рослинництва ім. В. Я. Юр'єва НААН

Наведено результати вивчення посухостійкості сортів колекції ріпака озимого «00» та «+0» типу на розчинах сахарози за осмотичного тиску у 10 , 14, 16 атмосфер. Виявлено, що умови південного сходу України сприяють формуванню більшої посухостійкості у сортів «00» типу. 3'ясовано, що між інтенсивністю росту корінців на контролі з інтенсивністю росту корінців на розчині сахарози існує слабкий негативний зв'язок ( $3 \mathrm{r}=-0,18 \pm 0,19$ до $r=-0,28 \pm 0,12)$, зі схожістю насінин на розчинах сахарози - суттєвий позитивний зв'язок ( $3 \mathrm{r}=0,63 \pm 0,15$ до $\mathrm{r}=0,28 \pm 0,19$ ).

Ріпак озимий, сахароза, осмотичний тиск, схожість, інтенсивність проростання

Харківська область розташована у межах двох фізико-географічних зон - Лісостепу і Степу. За особливостями гідротермічних ресурсів і відповідним для цих зон грунтовим покривом іiі територія розподіляється на шість грунтово-екологічних районів. За умовами холодного періоду листопад - березень вони практично не відрізняються. Істотна відмінність проявляється у вологозабезпеченні першої (травень - липень) і третьої (серпень вересень) частин теплого періоду. Якщо навесні спостерігається, в основному, повітряна посуха, то наприкінці літа - початку осені - повітряна і грунтова, що певним чином відображається на особливостях грунту i, як наслідок, на відтворенні сортами ріпака озимого адаптивного, продуктивного потенціалів та якості насіння.

Численні дослідники [1 - 5] стверджують, що одним з найважливіших періодів під час вегетації ріпаку є період з проростання насіння до фази формування третього справжнього листочка, коли відбувається інтенсивний ріст корінця. Це той період, сприятливі умови проходження якого, гарантують не тільки вирівняність посіву, синхронність основних фаз вегетації у рослин (цвітіння, жовтого стручка, повної стиглості таке інше), а і підготовку рослин до зимівлі та отримання сталого урожаю.

Оптимальні строки сівби ріпака озимого в Харківській області 25 серпня - 5 вересня, тобто у другій частині теплого періоду, який за багаторічними спостереженнями відрізняється браком опадів та відносно висо-

(C) Н. А. Глухова. 2012.

ISSN 0582-5075. Селекція і насінництво. 2012. Випуск 102. 
ким температурним режимом. Таким чином, для Харківської області актуальним є первинна оцінка вихідного матеріалу на посухостійкість і ідентифікація зразків, використання яких гарантувало б не тільки сходи, а і інтенсивний розвиток рослин ріпака восени.

Одним $з$ найбільш розповсюджених методів визначення посухостійкості є польовий [6], коли за станом рослин спостерігають в природних умовах і в посушливий період. Але недоліками польового методу є те, що він потребує багаторічних спостережень і може бути застосований тільки за наявності посухи, яка має часовий характер не тільки за роками, а і протягом всього року.

Для визначення зразків ріпака з посухостійкістю раннього етапу онтогенезу найбільш придатним є метод пророщування насіння на розчинах цукрози різного осмотичного тиску.

Пророщування рослин у розчині цукрози моделює проростання рослин у грунтовому розчині - волозі з особливим складом речовин, що знаходиться у грунті [7]. В свою чергу склад речовин грунтового розчину обумовлює його осмотичний тиск, який швидко зростає 3 підвищенням концентрації розчинних сполук. Осмотичний тиск грунтового розчину у різних грунтів неоднаковий і коливається від 1-3 до 10-20 атм. Нормальне споживання рослинами вологи і поживних речовин відбувається тільки за умови, коли осмотичний тиск грунтового розчину нижче осмотичного тиску клітинного соку кореневої системи рослин. У більшості культурних рослин осмотичний тиск клітинного соку знаходиться у межах 1-3 атм, а у деяких сягає 5-8 атм. Якщо осмотичний тиск грунтового розчину вищий, ніж у клітинному сокові, то надходження води і елементів живлення в рослину припиняється [8].

Все вищевикладене і стало передумовою наших досліджень.

Дослідження проводили в лабораторних і польових умовах Інституту рослинництва ім. В. Я. Юр'єва НААН у 2010-2012 рр. В якості вихідного матеріалу використовували зразки колекції ріпака озимого різного за географічним і генетичним походженням. Вивчали вісім сортів селекції ІваноФранківського інституту агропромислового виробництва (м. ІваноФранківськ), два сорти Інституту землеробства (м. Київ), п’ять сортів Національного аграрного університету (м. Київ), один сорт Вінницької дослідної станції (м. Вінниця), три сорти Інституту олійних культур, п’ять сортів OSEVA PRO r.s.v. (Чехія), один сорт з Польщі, два сорти Raps GBR (Німеччина), один сорт ВНИИМК (Росія). Зразки ріпака озимого відносились до сортів «00» типу та сортів «+0» типу. Для визначення посухостійкості насіння ріпаку пророщували на розчинах сахарози з осмотичним тиском у 10, 14 та 16 атмосфер за температури $22^{\circ} \mathrm{C}$. Підрахунок пророслого насіння проводили на третій, п'ятий і сьомий день. Корінці вимірювали на сьомий день досліду. В польових та лабораторних умовах проводили аналіз рослин перед входженням у зиму. Викопували рослини в полі, відмивали від землі, проводили зважування коренів та листя, вимірювали довжину коренів та діаметр кореневої шийки. Проводили кореляційний аналіз прямолінійної залежності [9]. 
В лабораторних умовах для визначення посухостійкості ріпака використовували метод оцінки посухостійкості, розроблений на пшениці, ячменю і кукурудзі за ступенем проростання насіння в різних розчинах сахарози. Наші дослідження показали, що сорти ріпака озимого неоднозначно реагували на розчини сахарози з різним атмосферним тиском (табл. 1).

Таблиця 1

Схожість насіння за пророщування на розчинах сахарози різного тиску, $\%$ до контролю

\begin{tabular}{|c|c|c|c|c|c|}
\hline \multirow{2}{*}{$\begin{array}{l}\text { № } \\
\Pi / \Pi\end{array}$} & \multirow{2}{*}{ Назва зразка } & \multirow{2}{*}{$\begin{array}{c}\text { Походження } \\
\text { зразка }\end{array}$} & \multicolumn{3}{|c|}{$\begin{array}{c}\text { Кількість пророслих насінин, } \\
\text { \% до контролю }\end{array}$} \\
\hline & & & $\begin{array}{c}10 \\
\text { атмосфер }\end{array}$ & $\begin{array}{c}14 \\
\text { атмосфер }\end{array}$ & $\begin{array}{c}16 \\
\text { атмосфер }\end{array}$ \\
\hline & \multicolumn{5}{|c|}{ Сорти «00» типу } \\
\hline 1 & Свєта & ІФІАПВ & 77 & 34 & 14 \\
\hline 2 & Дембо & $-"-$ & 92 & 30 & - \\
\hline 3 & Галицький & $-"-$ & 12 & 6 & - \\
\hline 4 & Дангал & $-"-$ & 100 & 62 & 26 \\
\hline 5 & Тисменицький & $-"-$ & 50 & 18 & 16 \\
\hline 6 & Дема & $-"-$ & 52 & 6 & - \\
\hline 7 & Чемпіон України & I3 & 59 & - & - \\
\hline 8 & Сенатор Люкс & $-"$ - & 100 & 72 & 12 \\
\hline 9 & Синтетік & НАУ, Київ & 11 & - & - \\
\hline 10 & Аліот & $-"-$ & 64 & - & - \\
\hline 11 & Соло & $-"-$ & 64 & - & - \\
\hline 12 & Майдан & $-"-$ & 58 & - & - \\
\hline 13 & Форвард & $-"-$ & 100 & 32 & 8 \\
\hline 14 & Чорний велетень & Вінницька ДС & 100 & 91 & 18 \\
\hline 15 & Антарія & IOK & 97 & 73 & 27 \\
\hline 16 & Анна & $-"-$ & 86 & 54 & 43 \\
\hline 17 & Атлант & $-"-$ & 100 & 65 & 55 \\
\hline 18 & ОП-БН-13 & Чехія & 76 & - & - \\
\hline 19 & ОП-БН-07 & $-"-$ & 63 & 14 & - \\
\hline 20 & ОП-БН-09 & $-"-$ & 85 & 14 & - \\
\hline 21 & ОП-БН-10 & $-"-$ & 86 & - & - \\
\hline 22 & Декатлон & $-"-$ & 75 & - & - \\
\hline \multirow{2}{*}{\multicolumn{6}{|c|}{\begin{tabular}{r|r}
$\mathrm{x}$ & 73 \\
Сорти « & $7 »$ типу
\end{tabular}}} \\
\hline & & & & & \\
\hline 23 & Dolnoslaski & Польща & 100 & 15 & 10 \\
\hline 24 & Emerald & Німеччина & 80 & 35 & 35 \\
\hline 25 & Marens & $-"-$ & 100 & 45 & 37 \\
\hline 26 & Успіх & ІФІАПВ & 90 & 52 & 45 \\
\hline 27 & Федорівський & $-"-$ & 90 & 70 & 28 \\
\hline 28 & Діана & Росія & 100 & 44 & 36 \\
\hline & & $-\mathrm{x}$ & 93 & 44 & 32 \\
\hline
\end{tabular}


Сорти «00» типу за середніми значеннями за різної концентрації розчинів сахарози мали більш низьку схожість, ніж сорти «+0» типу. Так, сорти «00» типу на розчині у 10 атмосфер кількість пророслих насінин дорівнювала $73 \%$ проти $93 \%$ у сортів «+0» типу, на розчині у 14 атмосфер - $26 \%$ проти $44 \%$, на розчині у 16 атмосфер - $10 \%$ проти $32 \%$.

Найбільшу диференціацію, порівняно з сортами «+0» типу, мали сорти «00» типу. Так, найбільшу втрату схожості насіння зазнали сорти чеської селекції, селекції Інституту землеробства та Національного аграрного університету, м. Київ.

Сорти селекції Івано-Франківського АПВ показали широкий діапазон посухостійкості. Найбільшу стабільність за посухостійкістю мав сорт Дангал, кількість пророслих насінин на розчині сахарози у 10 атмосфер дорівнювала $100 \%, 14$ атмосфер - 62 \%, 16 атмосфер - $16 \%$. Значну втрату схожості насіння зазнали сорти Демо і Галицький. Кількість пророслого насіння на розчині у 14 атмосфер дорівнювала лише $6 \%$.

Найкращу посухостійкість та іï стабільність показали сорти селекції Вінницької ДС та Інституту олійних культур. Схожість насіння на розчині сахарози у 16 атмосфер - найбільш несприятливому для проростання насіння середовищі, у сорту Атлант дорівнювала $55 \%$, Анна - 43 \%, Антарія $27 \%$, Чорний велетень $-18 \%$.

Таким чином, за аналізом наших досліджень та з огляду географічного розташування науково-дослідних установ, можна зробити висновок, що вища посухостійкість новостворених сортів «00» типу формується в умовах південного сходу. У сортів «+0» типу такої залежності не виявлено. Вірогідною причиною може бути те, що для цих сортів характерним є у меншому ступені змінений до дикого типу біохімічний склад насіння. Тобто, тих природних сполук, які здатні сприяти відтворенню адаптивного потенціалу.

Розчини сахарози різного осмотичного тиску мали вплив не тільки на ступінь проростання насіння, але і на інтенсивність коренеутворення. Так, насіння сортів чеської селекції із збільшенням концентрації розчину за формування пагона у більшості випадків не формували корінець. Така ж тенденція була притаманна сортам Національного аграрного університету та сорту Галицький Івано-Франківського АПВ.

Слід сказати, що сортам чеської селекції притаманна також суттєвою диференціація за інтенсивністю коренеутворення і за пророщування на воді. Розбіжність між довжиною корінців на сьомий день досліду сягала від 60 мм до 120 мм. Сорти Інституту олійних культур, для яких характерний високий ступінь посухостійкості, порівняно із чеськими сортами, формували на $17-25 \%$ коротші корінці. Сорти «+0» типу такої тенденції не мали. Можна припустити, що посухостійкі сорти здатні утворювати невелику кореневу систему, порівняно з непосухостійкими.

У селекції ріпака на посухостійкість важливим є також визначення зв'язку між ознаками. Нашими дослідами було вивчено взаємозв'язок між інтенсивністю росту коренів на контролі з інтенсивністю росту корінців та 
схожістю насінин на розчинах сахарози різного осмотичного тиску (табл. 2). Виявлено, що між інтенсивністю росту корінців на контролі з інтенсивністю росту корінців на розчині сахарози існує слабкий негативний зв'язок. Причому із збільшенням концентрації розчину цей зв'язок посилюється. Так, за осмотичного тиску розчину сахарози у 10 атмосфер $r=-0,18 \pm 0,19$, у 14 атмосфер $r=-0,26 \pm 0,17$, у 16 атмосфер $r=-0,28 \pm 0,12$. Навпаки, між інтенсивністю росту корінців на контролі та схожістю насінин на розчинах сахарози існує суттєвий позитивний зв'язок, який зменшується із підвищенням концентрації розчину. Так, за осмотичного тиску розчину сахарози у 10 атмосфер $\mathrm{r}=0,63 \pm 0,15$, у 14 атмосфер $\mathrm{r}=0,62 \pm 0,15$, у 16 атмосфер $\mathrm{r}=0,28 \pm 0,19$.

Таблиця 2

Кореляційні зв’язки між ознаками посухостійкості ріпака

\begin{tabular}{|c|l|c|}
\hline $\begin{array}{c}\text { № } \\
\text { п/п }\end{array}$ & \multicolumn{1}{|c|}{ Ознаки } & $\begin{array}{c}\text { Коефіцієнт } \\
\text { кореляції }\end{array}$ \\
\hline 1. & $\begin{array}{l}\text { Інтенсивність росту коренів на контролі - } \\
\text { Інтенсивність росту коренів на розчині сахарози у } \\
10 \text { атмосфер }\end{array}$ & $-0,18 \pm 0,19$ \\
\hline 2. & $\begin{array}{l}\text { Інтенсивність росту коренів на контролі - } \\
\text { Інтенсивність росту коренів на розчині сахарози у } \\
14 \text { атмосфер }\end{array}$ & $-0,26 \pm 0,17$ \\
\hline 3. & $\begin{array}{l}\text { Інтенсивність росту коренів на контролі - } \\
\text { Інтенсивність росту коренів на розчині сахарози у } \\
16 \text { атмосфер }\end{array}$ & $-0,28 \pm 0,12$ \\
\hline 4. & $\begin{array}{l}\text { Інтенсивність росту коренів на контролі - } \\
\text { Схожість насінин на розчині сахарози у } \\
10 \text { атмосфер }\end{array}$ & $0,63 \pm 0,15$ \\
\hline 5. & $\begin{array}{l}\text { Інтенсивність росту коренів на контролі - } \\
\text { Схожість насінин на розчині сахарози у } \\
14 \text { атмосфер }\end{array}$ & $0,28 \pm 0,19$ \\
\hline 6. & $\begin{array}{l}\text { Інтенсивність росту коренів на контролі - } \\
\text { Схожість насінин на розчині сахарози у } \\
16 \text { атмосфер }\end{array}$ \\
\hline
\end{tabular}

Висновки. Сорти «00» типу за різної концентрації розчинів сахарози мають більш низьку схожість та найбільшу диференціацію за рівнем посухостійкості, ніж сорти «+0» типу. Вірогідною причиною тому може бути їх більш високий ступень селектування.

Найкращу посухостійкість та ії стабільність показали сорти селекції Вінницької ДС та Інституту олійних культур. 
За аналізом наших досліджень та 3 огляду географічного розташування науково-дослідних установ більша посухостійкість новостворених сортів «00» типу формується в умовах південного сходу України. У сортів «+0» типу такої залежності не виявлено.

Насіння сортів чеської селекції із збільшенням концентрації розчину сахарози та за умов формування пагона у більшості випадків не формували корінець. Така ж тенденція була притаманна сортам Національного аграрного університету та сорту Галицький Івано-Франківського АПВ.

Сорти Інституту олійних культур, які характеризуються високим ступенем посухостійкості порівняно із чеськими сортами, формували на 17 25 \% коротші корінці. Сорти «+0» типу такої тенденції не мають.

Між інтенсивністю росту коренів на контролі з інтенсивністю росту корінців на розчині сахарози існує слабкий негативний зв'язок. Із збільшенням концентрації розчину цей зв'язок посилюється $3 \mathrm{r}=-0,18 \pm 0,19$ до $\mathrm{r}=-0,28 \pm 0,12$.

Між інтенсивністю росту корінців на контролі та схожістю насінин на розчинах сахарози існує суттєвий позитивний зв'язок, який із підвищенням концентрації розчину зменшується з $\mathrm{r}=0,63 \pm 0,15$ до $\mathrm{r}=0,28 \pm 0,19$.

\section{Список використаних джерел}

1. Що потрібно знати про ріпак? Запитання - відповіді / [М. І. Абрамик, В. Д. Гайдаш, В. О. Мазур, С. Й. Гуринович]. - Івано-Франківськ, 2007. $60 \mathrm{c}$.

2. Бардин Я. Б. Ріпак: від сівби до переробки / Я. Б. Бардин. - Київ: ТОВ “Універсал-Друк", 2006. - 102 с.

3. Рапс, сурепица: ботаническая характеристика, биологические особенности, технология возделывания, сорта и семеноводство, использование, зарубежный опыт / [А. А. Гольцов, А. М. Ковальчук, В. Ф. Абрамов, Н. З. Милащенко]. - М.: Колос, 1983. - 192 с.

4. Інтенсивна технологія вирощування озимого ріпаку в Україні / [T. І. Лазарь, О. М. Лапа, А. В. Чехов, І. М. Свидинюк, М. І. Абрамик, П. С. Вишнівський, В. А. Санін, А. О. Касьян]. - Київ: ТОВ "УніверсалДрук", 2006. - 102 с.

5. Лихочвор В. В. Ріпак / В. В. Лихочвор, Р. Р. Проць. - Львів : НВФ "Українські технології", 2005. - 88 с.

6. Шматько И. Г. Устойчивость растений к водному и температурному стрессам / И. Г. Шматько, И. А. Григорюк, О. Е. Шведова. - Львов : Наукова думка, 1989. - 212 с.

7. Адаптация растений к экстремальным условиям увлажнения. - Кишинев : Штиинца, 1984. - 58 с.

8. Энциклопедия научной библиотеки. enc.sci-lib.com/article 0001054.html

9. Основи наукових досліджень в агрономії / [В. О. Сщенко, П. Г. Копитко, В. П. Опришко, П. В. Костогриз]. - Київ : Дія, 2005. - 288 с. 
Приведены результаты изучения засухоустойчивости сортов коллекции рапса озимого «00» и «+0» типа на растворах сахарозы с осмотическим давлением в 10, 14, 16 атмосфер. Установлено, что более высокая засухоустойчивость сортов «00» типа формируется в условиях юго-востока. Определено, что между интенсивностью роста корешков на контроле с интенсивностью роста корешков на растворах сахарозы существует слабая отрицательная связь (с $\mathrm{r}=-0,18 \pm 0,19$ до $\mathrm{r}=-0,28 \pm 0,12)$, со всхожестью семян на растворах сахарозы - существенная положительная связь (с $\mathrm{r}=0,63 \pm$ $0,15$ до $\mathrm{r}=0,28 \pm 0,19)$.

Results of the studies about the drought-resistance of winter-annual " 00 " and " +0 " types of the rape collection on solutions of saccharose with an osmolality of $10,14,16$ atmospheres are presented. It is estrablished that the larger drought-resistance of " 00 " sorts is formed under the conditions of the south-east. It is discovered that between the intensity of the roots growth under the control with the intensity of the roots growth with the saccharose solutions there is a mild negative relation (with $r=-0,18 \pm 0,19$ to $r=-0,28 \pm 0,12$ ) with the germination of seed on saccharose solutions - substantial positive relation (with $r=0,63 \pm$ 0,15 to $r=0,28 \pm 0,19$ ). 